\title{
CANINE DISTEMPER VIRUS INFECTION WITH SECONDARY Bordetella bronchiseptica PNEUMONIA IN DOGS
}

\author{
INFECÇÃO PELO VIRUS DA CINOMOSE COM PNEUMONIA SECUNDÁRIA \\ POR Bordetella bronchiseptica EM CÃES
}

\author{
Selwyn Arlington Headley ${ }^{1}$, Dominguita Lühers Graça ${ }^{2}$, Mateus Matiuzzi da Costa ${ }^{3}$, \\ Agueda Castagna de Vargas ${ }^{4}$
}

\section{- CASE - REPORT -}

\section{SUMMARY}

Canine distemper virus infection and secondary Bordetella bronchiseptica pneumonia are described in mongrel dogs. Canine distemper was characterised by nonsuppurative demyelinating encephalitis with typical inclusion bodies in astrocytes. B. bronchiseptica was isolated from areas of purulent bronchopneumonia.

Key words: dogs, canine distemper virus, Bordetella bronchiseptica, nonsuppurative demyelinating encephalitis.

RESUMO

São descritas as infecções simultâneas do vírus da cinomose canina e Bordetella bronchiseptica em caninos sem raça definida. As lesões de cinomose foram caracterizadas por encefalite desmielinizante associada a corpúsculos de inclusão em astrócitos. B. bronchiseptica foi isolada das áreas com broncopneumonia supurativa.

Palavras-chave: cães, vírus da cinomose canina, Bordetella bronchiseptica, encefalite desmielinizante nãosupurativa.

\section{INTRODUCTION}

Canine distemper virus (CDV) is a Morbillivirus, family Paramyxoviridae, with worldwide distribution that occurs in all members of the
Canidae, Mustelidae, and Procyonidae families (APPLE, 1987; DUNGWORTH, 1993; SUMMERS et al., 1994). Distemper is the principal cause of death of dogs submitted for necropsy in our laboratory and is considered enzootic within the city of Santa Maria, RS (HEADLEY \& GRAÇA, 1998).

Distemper could result in systemic infections and clinical manifestations may be observed in any organ system (APPLE, 1987; DUNGWORTH, 1993). Lesions are more pronounced when secondary infections are present (DUNGWORTH, 1993). Neurologic manifestations are generally fatal, and may be responsible for the high morbidity and mortality in dogs unvaccinated or inadequately vaccinated (APPLE, 1987).

CDV-induced immunosupression in infected dogs results in severe secondary bacterial pulmonary infections by Bordetella bronchiseptica (SWANGO, 1989; DUNGWORTH, 1993), and may cause the activation of latent protozoan infections (TIPOLD et al., 1992; DUNGWORTH, 1993), normally in association with clinical manifestations of Toxoplasma gondii (TIPOLD et al., 1992; DUNGWORTH, 1993; SUMMERS et al., 1994), or Neospora caninum (TIPOLD et al., 1992).

\footnotetext{
${ }^{1}$ Mestrando do Programa de Pós-graduação em Medicina Veterinária, Universidade Federal de Santa Maria (UFSM), Bolsista CAPES.

${ }^{2}$ Professor Titular, Medico Veterinário, PhD., Departamento de Patologia, UFSM, 97105-900, Santa Maria, RS, Brasil. E-mail: dlgraca@lince.hcv.ufsm.br. Autor para correspondência.

${ }^{3}$ Aluno, Curso de Medicina Veterinária, Bolsista CNPq/PIBIC, UFSM.

${ }^{4}$ Professor Assistente, Médico Veterinário, MSc., Departmento de Medicina Veterinária Preventiva, UFSM. Recebido para publicação em 01.12.98. Aprovado em 03.02.99
} 
This report describes the gross and microscopic findings of CDV infection associated with secondary bacterial pneumonia induced by Bordetella bronchiseptica in two dogs submitted for routine necropsy.

\section{CASE REPORT}

Two mongrel dogs clinically diagnosed as having bronchopneumonia and suspected of CDV infection were submitted for necropsy at the Veterinary Pathology Unit, Federal University of Santa Maria (SPV/UFSM), Santa Maria, Rio Grande do Sul, Brazil. Both dogs were housed at the Veterinary Hospital (HCV/UFSM). Dog number one, a male of 18 months of age, was unvaccinated, had progressive weight loss, purulent ocular discharge, corneal opacity of the left eye, persistent cough, and died suddenly. Dog number two, a fivemonth old female, was vaccinated at three months of age, developed a chronic cough of about thirty days duration, during which purulent ocular and nasal discharges were observed. The referring veterinarian administered benzetacil for seven days, followed by gentamycin during another ten days. However, no pulmonary relief was obtained, and a switch was made to trimethoprim and sulphadiazine, also without any further success. Pulmonary distress worsened and euthanasia was realised.

Both dogs were necropsied shortly after death. Both were in good body condition and had purulent ocular secretion, but abdominal pustules were present only in dog number two. Selected areas from the brain, lung, stomach, urinary bladder, kidney, lymph nodes, and liver of both dogs were collected, fixed in $10 \%$ formalin solution, and routinely processed for histopathology. Specimens of infected pulmonary tissue were collected asseptically and sent for bacterial evaluation. Bacteriological evaluation was based on methods described by QUINN et al. (1994). Pulmonary specimens were cultured in $8 \%$ ovine blood agar and Mac Conkey agar, and morphological, staining, and biochemical characteristics were analysed after 48 hour of incubation at $37^{\circ} \mathrm{C}$.

\section{RESULTS AND DISCUSSION}

Nervous tissues were unaltered at necropsy. However, microscopic examination revealed non-suppurative demyelinating encephalitis in both cases. Various areas of demyelination with eosinophilic intranuclear inclusion bodies characteristic of $\mathrm{CDV}$, principally in astrocytes, were observed in the cerebellum. Associated to these areas of white matter demyelination were perivascular cuffs, formed by two to three layers of mononuclear cells and lymphocytes, discrete gliosis, and moderate astrogliosis.

Gross pulmonary alterations were similar with little individual variation. The pleura was smooth and glistening. Areas of consolidation, and other large irregular shaped, greenish-grey, slightly depressed areas were seen, principally at the border of some pulmonary lobes. Pulmonary sections revealed multiple, different sized, pus-filled areas, with marked accumulation of oedematous fluid within the tracheal air space. Histopathological evaluation revealed severe purulent broncopneumonia. In these cases, marked accumulation of degenerated neutrophils in bronchial and alveolar air spaces, necrosis of bronchiolar and bronchial epithelial cells, small isolated foci of severe necrosis, scattered haemorrhagic areas, and intralesional bacteria were observed. Pulmonary specimens revealed pure cultures of Bordetella bronchiseptica. Other significant gross lesions were hemorrhagic and enlarged regional lymph nodes of dog two, which corresponded to severe cortical haemorrhage with moderate depletion of lymphatic tissues and absence of cortical-medular differentiation microscopically.

A diagnosis of canine distemper virus (CDV) was based on multifocal non-suppurative demyelinating encephalitis in which eosinophilic intranuclear inclusion bodies characteristic of canine distemper virus were observed in astrocytes (DUNGWORTH, 1993; SUMMERS et al., 1994), while cultures characteristic of Bordetella bronchiseptica (QUINN et al., 1994), were isolated from the lungs.

The clinical manifestations seen in these dogs have already been associated with CDV infection (SWANGO, 1989; DUNGWORTH, 1993). Dog number two presented abdominal pustules, which are thought to be the result of streptococci and staphylococci bacterial complications and normally considered as cutaneous manifestation of CDV infection (DUNGWORTH, 1993).

The bacterial isolation of Bordetella bronchiseptica from these dogs, with purulent bronchopneumonia, should be considered as secondary to CDV infection, being directly related to the immunosupressive action of this virus on lymphatic tissues (SWANGO, 1989; DUNGWORTH, 1993), and the result of apoptosis (MORO \& VASCONCELOS, 1998), or necrosis and subsequent viral multiplication (DUNGWORTH, 1993), as was the case of dog number one. Further, most classical clinical manifestations of toxoplasmosis or neosporosis are related to immunosupression by $\mathrm{CDV}$ or another viral agent (TIPOLD et al., 1992). 
The association described in dogs of this report is important in increasing the mortality of dogs affected by CDV (SWANGO, 1989). Therefore, caution should be taken by veterinary practitioners when treating bacterial infections in which distemper, other encephalitides, or infectious agents are suspected as occurring concomitantly. Additionally, vaccination programmes, aimed at distemper and other infectious canine diseases considered enzootic, should be adapted, and maintained in urban dog populations, in an attempt to combat such infections and reduce the chance of opportunistic bacterial or other infections.

\section{REFERENCES}

APPLE, M.J.G., Canine distemper virus. In: APPLE, M.J.G., Virus infections of carnivores, The Netherlands: Elsevier, 1987. Cap. 13, p.133-159.

APPLE, M.J.G., Canine distemper virus. In: APPLE, M.J.G., Virus infections of carnivores, The Netherlands: Elsevier, 1987. Cap. 13, p.133-159.
HEADLEY, S.A., GRAÇA, D.L., Canine distemper: a retrospective epidemiological study, In: $1^{\mathrm{A}}$ REUNION ARGENTINA DE PATOLOGÍA VETERINARIA, 1998, Esperanza, Santa Fé, Argentina. Acta de Resúmenes... Santa Fé: Universidad Nacional del Litoral, 1998. 40 p. p. 24.

MORO, L., VASCONCELOS, A.C., Patogenia da imunossupressão na cinomose canina, Hora Veterinária, ano. 107, n. 102, p. 53-57, 1998.

MURRAY, P.R., BARON, E.J., PFALLER, M.A., et al., Manual of clinical microbiology. 6 ed. Washington, D.C: ASM, 1995. $1482 \mathrm{p}$.

QUINN, P.J., CARTER, M.E., MARKEY, B., et al., Clinical veterinary microbiology. London: Wolfe, 1994. 648p.

SUMMERS, B.A., CUMMINGS, J.F., de LAHUNTA, A., Veterinary Neuropathology, Missouri: Mosby, 1994. Cap. 3, p. 102-110.

SWANGO, L.J., Canine viral diseases. In: ETTINGER, S.J., Textbook of veterinary internal medicine. 3. ed. Philadelphia: Saunders, 1989. Cap. 47, p. 301-303.

TIPOLD, A., VANDEVELDE, M., JAGGY, A., Neurological manifestations of canine distemper virus infection, J Sm An Pract, v. 33. p. 466-470, 1992.

Ciência Rural, v. 29, n. 4, 1999. 